\title{
NILAI-NILAI KEISLAMAN PADA MATERI POKOK IPS DALAM BUKU TEMATIK KELAS IV SD/MI TEMA "PEDULI TERHADAP MAKHLUK HIDUP"
}

\author{
Rina Rahmi \\ STAIN Teungku Dirundeng Meulaboh \\ Email: rina.rahmi@staindirundeng.ac.id
}

\begin{abstract}
Abstrak
Penelitian ini bertujuan untuk mengkaji dan menganalisis nilai-nilai keislaman yang terdapat pada materi pokok IPS dalam buku tematik kelas IV SD/MI tema 3 "Peduli Terhadap Makhluk Hidup" edisi revisi 2017 terbitan Kementerian Pendidikan dan Kebudayaan. Jenis penelitian menggunakan penelitian kualitatif metode library research./Content Analysis. Sumber data dalam penelitian ini berupa sumber data primer yaitu buku tematik (buku guru dan siswa) kelas IV SD/MI semester I (satu). Pengumpulan data menggunakan teknik dokumentasi. Sedangkan analisis data menggunakan teori Miles and Huberman yang terdiri dari reduksi data, penyajian data, dan penarikan kesimpulan. hasil penelitian ini menunjukkan bahwa nilai-nilai keislaman yang terkandung dalam materi pokok IPS buku Tematik tema 3 terdapat 4 dari 18 nilai karakter yang dikemukakan oleh Pusat Kurikulum Badan Penelitian dan Pengembangan yang terdiri dari Nilai Aqidah berupa religius dna tanggung jawab; Nilai Ibadah berupa Peduli Lingkungan, dan Nilai Akhlak berupa disiplin.
\end{abstract}

Kata Kunci: Nilai-Nilai Keislaman, Materi Pokok IPS, dan Buku Tematik

\begin{abstract}
This research aims to examine and analyze the Islamic values contained in the subject matter of Social Science in the thematic book for grade IV Elementary School theme 3 "Care for Living Creatures" revised 2017 edition of the Ministry of Education and Culture. This type of research uses a qualitative research method library research / Content Analysis. Sources of data in this study in the form of primary data sources, namely thematic books (teacher and student books) grade IV Elementary School semester I (one). Data collection using documentation techniques. Meanwhile, data analysis used the theory of Miles and Huberman which consisted of data reduction, data presentation, and concluding. the results of this study indicate that the Islamic values contained in the subject matter of Social Sciences Thematic book theme 3 there are 4 of the 18 character values proposed by the Curriculum Center of the Research and Development Agency consisting of Aqidah values in the form of religious and responsibility; Worship values in the form of Environmental Care, and Moral Values in the form of discipline.
\end{abstract}

Keywords: Islamic Values, Social Studies Main Materials, and Thematic Books 


\section{PENDAHULUAN}

Pendidikan Nasional sebagaimana disebutkan UU nomor 20 tahun 2003 berfungsi untuk mengembangkan potensi peserta didik dan membentuk tingkah laku juga kemajuan bangsa yang bermartabat guna mencerdasakan kehidupan bangsa dengan tujuan mewujudkan manusia yang beriman dan takut kepada Tuhan YME, berakhlakul karimah, sehat, berilmu, cakap, kreatif, mandiri, dan menjadi warga negara yang demokratis serta bertanggung jawab. (Depdiknas, n.d. 2003:5) Untuk mencapai tujuan sebagaimana yang dimaksud dalam UU tersebut, seorang pendidik dituntut untuk benar-benar menguasai materi yang akan disampaikan dan mampu menambah wawasannya sesuai dengan perkembangan ilmu pengetahuan. Untuk itu, buku teks sangat dibutuhkan oleh pendidik (Mumpuni, 2018:45).

Buku teks digunakan sebagai pegangan wajib pendidik dan peserta didik satuan pendidikan tertentu sebagai salah satu media pembelajaran dalam suatu mata pelajaran yang digunakan guna mencapai tujuan yang mempunyai peranan penting dalam menentukan kualitas pendidikan. Selain bisa membantu proses pembelajaran, buku teks bisa dipelajari peserta didik kapan dan dimana saja. buku teks tersebut memuat ilmu pengetahuan dan sejumlah informasi, serta memperdalam informasi yang sudah diketahui sebelumnya (Mumpuni, 2018:44). Pendapat lain menguraikan bahwa jenis buku teks yang dipakai guru dan siswa pada jenjang sekolah dasar dan menengah ialah buku teks utama sebagai pokok untuk pendidik dan peserta didik, dan buku teks pelengkap untuk memperkaya ilmu sebagai tambahan dari buku teks utama (Suyatinah, 2001:9). Buku teks digunakan pada pendidikan tingkat dasar dan menengah (Peraturan Menteri Pendidikan dan Kebudayaan Republik Indonesia, Tentang Buku Teks Pelajaran dan Buku Panduan Guru untuk Pendidikan Dasar dan Meenengah Nomor 71, 2013:1). Pada satuan pendidikan, terdapat dua jenis buku teks yang digunakan, yang terdiri dari buku teks pelajaran dan non pelajaran. Kedua jenis buku teks ini digunakan untuk meningkatkan pengetahuan pada jenjang pendidikan yang lebih tinggi (Peraturan Menteri Pendidikan dan Kebudayaan Republik Indonesia, Salinan Lampiran Nomor 8 tentang Buku yang digunakan oleh Satuan Pendidikan, 2016:1).

Sementara itu, Pendidikan di Indonesia saat ini menggunakan kurikulum 2013 yang berorientasi pada kompetensi sikap, pengetahuan, dan keterampilan. Pada jenjang pendidikan Sekolah Dasar, implementasi kurikulum 2013 dilaksanakan melalui pembelajaran tematik terpadu mulai dari kelas I sampai kelas VI (Hakim \& Imam Nur, 2014:46). Berkaitan dengan hal ini, salah satu sumber belajar yang digunakan di SD/MI yaitu buku tematik terpadu, yang mana buku tematik ini sebaiknya tidak hanya berisi tentang ilmu pengetahuan saja, namun 
juga harus mengandung aspek mencerdaskan dan pendidikan karakter. Oleh karena itu, penting dipikirkan bentuk karakter seperti apa yang ditanamkan pada peserta didik. Hal ini berkaitan dengan pengembangan masalah keimanan dan ketakwaan. Implementasi pembelajaran tematik terpadu di laksanakan dengan cara mengintegrasikan berbagai kompetensi dan muatan mata pelajaran dalam satu tema (Triyanto, 2011:139). Salah satu mata pelajaran yang diintegrasikan dalam pembelajaran tematik ialah Ilmu pengetahuan Sosial (IPS). Ilmu Pengetahuan Sosial merupakan gabungan dari beberapa konsep ilmu sosial dengan konsep pendidikan yang diajarkan secara sistematik, psikologis, dan fungsional sesuai dengan perkembangan peserta didik (Riyadi, 2015:42). Pendidikan Ilmu Pengetahuan Sosial pada jenjang sekolah dasar sangat penting untuk dipelajari, hal ini disebabkan karena IPS bukanlah gambaran ilmu pengetahuan yang hanya sekedar isu, akan tetapi kajian ilmunya perlu untuk dikaji dan di analisis sesuai dengan fakta dan data yang diperoleh dari beragam sumber (Susanto, 2014:33).

Berkitan dengan hal tersebut, materi pokok IPS tidak hanya mengandung ilmu pengetahuan saja, akan tetapi mampu mengembangkan muatan IPS yang berkaitan dengan masalah keimanan dan ketakwaan peserta didik. Pendidik yang kreatif mempunyai kemungkinan untuk mengajak peserta didik mengembangkan sendiri materi pembelajarannya. Namun, kebanyakan pendidik sekarang ini hanya mengandalkan materi dan mengajarkannya sesuai dengan apa yang terdapat dalam buku pelajaran. Hal inni senada dengan pernyataan Risma Dwi Arisona yang mengemukakan bahwa kondisi pendidikan saat ini masih sedikit sekali yang bisa memecahkan masalah pendidikan. Salah satunya ialah tingkat SD/MI, yang mana keadaan pembelajaran dari segi pengelolaan dan pembelajaran yang dilaksanakannya masih belum terintegratif dan materi pendidikan yang dikembangkan menunjukkan hasil yang kurang menyenangkan. Menurutnya, hal ini dikarenakan materi yang disampaikan atau kurikulumnya masih bersifat parsial dan belum terintegral dengan kandungan nilai materi yang lain, terutama nilai-nilai keislaman (Arisona, 2017:330). Nilainilai keislaman dapat dikatakan sebagai dasar/tumpuan Islam yang paling penting. Dengan demikian, untuk memahami, mempelajari, mengamalkan, mengajar dan menanamkan nilainilai keislaman dalam kehidupan sehari-hari maka diperlukannnya pembelajaran, pengamalan, pendalaman dan pemahaman ilmu pengetahuan yang mengajarkan nilai-nilai keislaman dalam menjalani kehidupan ini (Ramdhani, 2015).

Dalam perkembangan kehidupan peserta didik, manusia tidak bisa terlepas dari nilai, baik itu nilai ilahiyah ataupun insaniyah. Proses transformasi nilai keislaman tersebut penting dilakukan secara tepat, karena pangamalan dari nilai-nilai tidak jarang berbenturan dengan Rina Rahmi | Nilai-Nilai Keislaman pada Materi Pokok IPS dalam Buku Tematik kelas IV SD/MI Tema "Peduli Terhadap Makhluk Hidup" | 91 
kondisi perkembangan kehidupan. Adapun transformasi nilai keislaman dalam ilmu pengetahuan sosial diterapkan melalui organisasi materi pembelajaran yang merupakan faktor penting dalam menanamkan nilai-nilai keislaman. Hal ini disebabkann karena materi pelajaran berfunngsi sebagai pesan yang disampaikan kepada peserta didik yang berupa pokok materi yang bisa ditransformasikan dalam ruang kesadaran peserta didik sehingga dapat berdampak pada perilaku (Kholidah, 2015: 325-340). Dengan demikian, penelitian ini akan mengkaji dan menganalisis nilai-nilai keislaman apa saja yang terdapat dalam buku tematik kelas IV SD/MI tema "Peduli Terhadap Makhluk Hidup" edisi revisi 2017 terbitan Kementerian Pendidikan dan Kebudayaan.

\section{KAJIAN TEORETIS}

\section{Nilai-Nilai Keislaman}

Nilai-nilai keislaman merupakan dua kata yang mempunyai makna yang saling berkaitan, yaitu nilai dan keislaman. Pada hakikatnya nilai ialah keyakinan yang mendorong manusia untuk melakukan sesuatu sebagai dasar pilihannya (Mulyana, 2004:9). Dengan demikian nilai keislaman bisa diartikan sebagai konsep juga keyakinan yang djunjung tinggi oleh setiap orang terhadap hal-hal yang berkaitan dengan agama yang kemudian menjadikannya sebagai pedoman dalam berperangai dikehidupan sehari-hari baik itu yang bersumber dari Allah ataupun hasil interaksi manusia yang tidak bertentangan dengan syari'at. Syari'at Islam mengajarkan nilai-nilai pokok ajaran agama yang mana apabila seseorang sudah mengaplikasikan nilai-nilai tersebut hingga mendarah daging dalam jiwanya maka ia akan mendapatkan kebahagiaan yang hakiki atau kebahagiaan yang sesungguhnya. Nilai-nilai pokok ajaran agama yang dimaksud ialah ajaran-ajaran yang terdapat dalam alQur'an dan as-Sunnah. Adapun nilai-nilai pokok keislaman (Ramdhani, 2015:7) sebagai berikut:

\section{a. Nilai Aqidah}

Aqidah mempunyai arti keyakinan atau kepercayaan, misalnya aqidah tentang adanya Allah dan Diutusnya para Rasul. Hal ini senada dengan pengertian yang dikutip oleh (Efendi, 2016:172) yang menyatakan bahwa aqidah merupakan keyakinan hidup yang mempunyai kekhasan seperti pengikraran yang bertolak dari nurani. Dengan demikian aqidah ialah sesuatu yang wajiib diyakini kebenarannya oleh hati, dapat memunculkan ketenteraman jiwa dan keyakinan tersebut tidak sedikitpun adanya keraguan (Safrida \& Andayani, 2016:1-2). Oleh karena itu, apa yang sudah menjadi ketetapan hati seseorang secara pasti ialah aqidah. Baik itu benar ataupun salah ('Abdul bin 'Abdul Hamid alAtsari, 2006).

Rina Rahmi | Nilai-Nilai Keislaman pada Materi Pokok IPS dalam Buku Tematik kelas IV SD/MI Tema "Peduli Terhadap Makhluk Hidup" | 92 


\section{b. Nilai Ibadah}

Ibadah mempunyai makna taat, patuh, dan merendahkan diri dihadapan yang disembah yaitu sang khaliq Allah SWT (Ramdhani, 2015:7). Dengan demikian, dapat diketahui bahwa nilai ibadah ialah nilai-nilai yang mencakup hal-hal yang disuka dan diridhoi Allah baik itu perkataan, perbuatan yang dilakukan secara terang-terangan ataupun sembunyi-sembunyi dengan tujuan untuk memuliakan Allah SWT. Ibadah menurut para ulama dibagi menjadi dua bagian, pertama ibadah yang sering dilakukan (ibadah mahdhah) yang meliputi sholat, zakat, puasa,dan haji. Kedua ibadah yang bersifat umum (ibadah 'Ammah) dan sering disebutkan ibadah ghairu mahdhah yang meliputi bekerja, makan, minum, istirahat dan lain sebagainya dengan maksud untuk menjaga kesehatan jasmani agar mampu melaksanakan ibadah kepada Allah sesuai dengan perintah dan mendapatkan ridho-Nya (Muftisany, 2016).

\section{c. Nilai Akhlak}

Akhlak merupakan kata jamak dari khuluq yang mempunyai makna kebiasaan, watak, tabi'at, perangai, adab ataupun sopan santun dan agama (Suwito, 2004:76). Kebiasaan, perangai, dan kecenderungan hati utnuk melakukan sesuatu atau perbuatan berubah menjadi etika (Tim Pengembangan Ilmu Pendidikan FIP-UPI, 2007:20). Dengan demikian, akhlak dapat didefinisikan sebagai suatu sifat yang tertanam dalam jiwa manusia yang mengatur tindakan dan tingkah laku. Cakupan akhlak tidak hanya pada dimensi horizontal saja (kemanusiaan), namun juga pada dimensi vertikal (Allah SWT) (Rasyid, 2000:47). Hal ini senada dengan pernyatan (Ramdhani, 2015:8) yang menyatakan bahwa cakupan akhlak tidak hanya pada dimensi kemanusiaan dan Allah SWT, namun juga meliputi akhlak terhadap alam.

Berkaitan dengan hal tersebut, (Fitriani, 2016:19) mendeskripsikan nilai-nilai keislaman menurut Kementerian Pendidikan Nasional menjelaskan bahwa nilai ialah sikap dan perilaku yang patuh dalam melaksanakan ajaran agama yang dianutnya, toleran terhadap pelaksanaan ibadah antar agama serta hidup rukun antar pemeluk agama lain. Dengan demikian, pendidikan Islam tidak hanya bersifat teoritis saja tetapi juga praktis. Penananaman nilai yang membutuhkan keteladanan dan harus dibiasakan, bukan diajarkan.

Jika Pusat Kurikulum Badan Penelitian dan Pengembangan terdapat 18 nilai karakter sebagaimana terlihat pada gambar berikut (Hasan \& Dkk, 2010:7-11): 


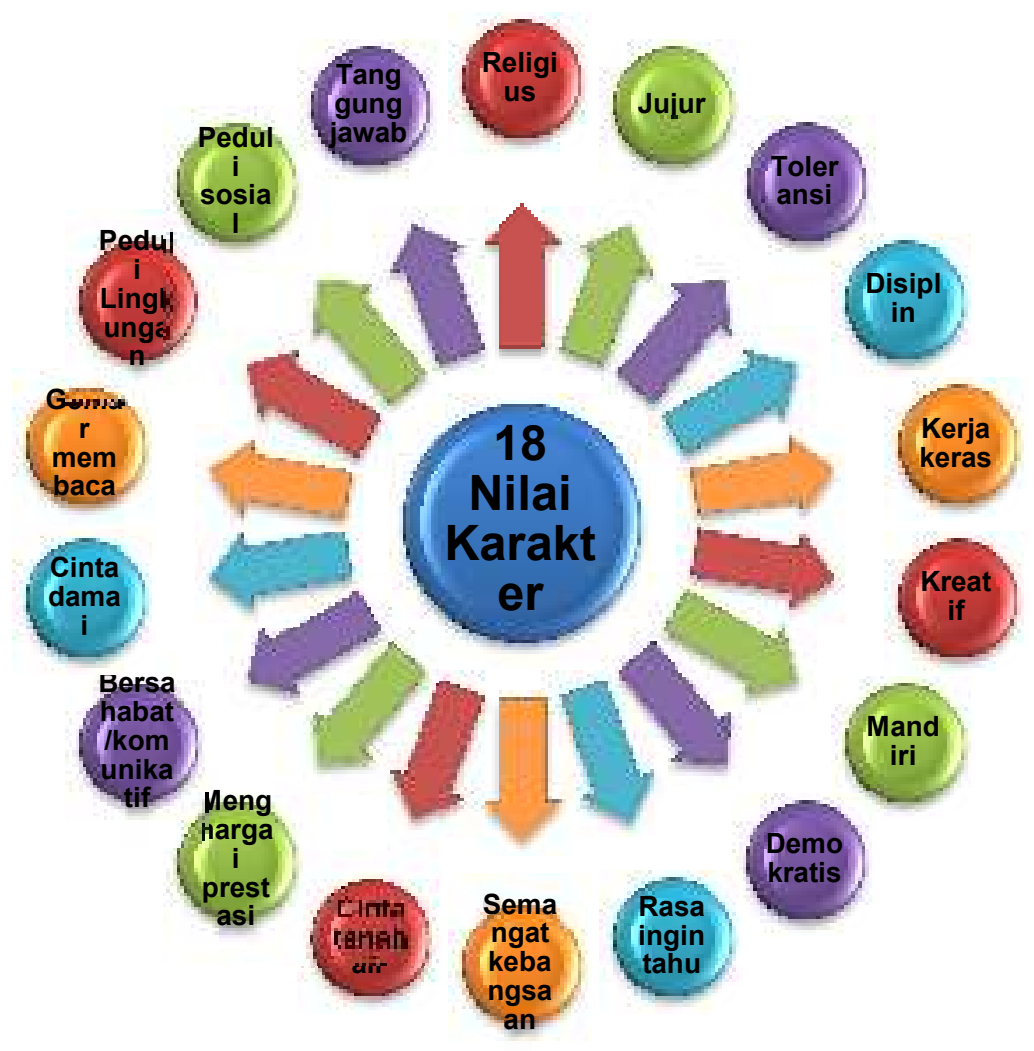

dalam perspektif al-Qur'an nilai karakter jauh melebihi angka tersebut. Namun untuk memudahkan penanaman nilai tersebut perlu dirumuskan secara sederhana sesuai dengan tingkat pendidikan itu sendiri. Paling tidak nilai-nilai itu bisa dikelompokkan dalam empat hal, yaitu:

a. Nilai yang terkait dengan hablun minallah (hubungan seorang hamba kepada Allah), seperti ketaatan, keikhlasan, syukur, sabar, tawakal, mahabbah, dan sebagainya.

b. Nilai yang terkait dengan hablun minannas, yaitu nilai-nilai yang harus dikembangkan seorang dalam hubungannya dengan sesama manusia, seperti tolongmenolong, empati, kasih-sayang, kerjasama, saling mendo'akan dan memaafkan, hormat-menghormati, dan sebagainya.

c. Nilai yang berhubungan dengan hablun minannafsi (diri sendiri), seperti: kejujuran, disiplin, amanah, mandiri, istiqamah, keteladanan, kewibawaan, optimis, tawadlhu', dan sebgainya.

d. Nilai yang berhubungan dengan hablun minal-'alaam (hubungan dengan alam sekitar), seperti keseimbangan, kepekaan, kepedulian, kelestarian, kebersihan, dan sebagainya. 


\section{METODE}

Jenis penelitian yang digunakan dalam penelitian ini ialah penelitian kualitatif(Darmawan, 2013:127). Sedangkan metode penelitiannya menggunakan metode library research atau kajian pustaka atau disebut juga dengan metode Content Analysis (Muliawan, 2014:71) guna memperoleh data penelitian sebagai pemanfaatan dari sumber perpustakaan (Zed, 2004:1-2). Sumber data yang digunakan dalam penelitian ini adalah subjek dimana data dapat diperoleh peneliti (Arikunto, 2020:172) dalam hal ini berupa dokumen-dokumen yang berkaitan dengan nilai-nilai keislaman dan materi pokok IPS dalam buku tematik. Adapun teknik pengumpulan datanya menggunakan teknik dokumentasi (Yusuf, 2017:372) yang dimanfaatkan untuk memperoleh data berupa catatan, transkrip, buku, dan lainnya (Trianto, 2010:278). Sedangkan tehnik analisis data yang terdiri dari: a) reduksi data, yaitu peneliti merangkum dan memilih data yang relevan dengan tujuan penelitian; b) penyajian data, peneliti menyajikan data secara singkat, baik berupa tabel, grafik, dan lainnya; c) verifikasi/kesimpulan (Miles \& Huberman, 1992:16) Dalam kegiatan ini, ada beberapa langkah yang harus diperhatikan dalam penelitian library research yaitu menyiapkan perlengkapan (pensil, pulpen, dan kertas catatn); menyiapkan blibiografi kerja; mengorganisasikan waktu; membaca dan mencatat bahan penelitian (Zed, 2004:74).

\section{HASIL DAN PEMBAHASAN}

Berdasarkan hasil analisis materi pokok IPS dalam buku tematik siswa kelas IV MI/SD terbitan kementerian pendidikan dan kebudayaan tema Peduli Terhadap Makhluk Hidup, Subtema 1-3 yang masing-masing subtema terdapat 6 pembelajaran dan secara umum terdiri dari 7 muatan mata pelajaran, yakni Bahasa Indonesia, Matematika, IPS, SDdP, PPKn, IPA dan PJOK. Sebagaimana yang telah di uraikan pada pembahasan sebelumnya, dalam hal ini penulis fokus pada salah satu dari mata pelajaran tersebut, yaitu IPS. Pada tema 3, mata pelajaran IPS ditemukan hanya pada pembelajaran 1 dan 5 dari setiap subtema yang ada. Selain itu, mata pelajaran yang diintegrasikan dengan pelajaran IPS pada tema ini hanya 3 yaitu Bahasa Indonesia, IPS dan IPA. Hal ini dapat diketahui berdasarkan hasil analisis yang dilakukan pada pemetaan KD pada buku guru sebagai penunjang untuk memperoleh data yang di analisis. Adapun KD IPS hanya terdapat pada pembelajaran 1 dan 5 dari setiap subtemanya. Dengan demikian, berikut penulis lampirkan kompetensi dasar IPS yang dirumuskan pada tema ini yakni KD (3.1) Mengidentifikasi karakteristik ruang dan pemanfaatan sumber daya alam untuk kesejahteraan masyarakat dari tingkat kota/kabupaten 
sampai tingkat provinsi; KD (4.1): Menyajikan hasil identifikasi karakteristik ruang dan pemanfaatan sumber daya alam untuk kesejahteraan masyarakat dari tingkat kota/kabupaten sampai tingkat provinsi (Anggari et al., 2017:3, 69,129). Dengan demikian, penulis akan menyajikan hasil analisis materi pokok Ilmu Pengetahuan Sosial (IPS) berdasarkan masingmasing subtema pada pembelajaran 1 dan pembelajaran 5 .

\section{Subtema 1 : Hewan dan Tumbihan di Lingkungan Rumahku}

Berdasarkan hasil analisis yang dilakukan pada subtema 1: hewan dan tumbuhan di lingkungan sekitarku, tujuan dan kegiatan pembelajaran yang tercantum dalam subtema 1 ialah:

a. Pembelajaran 1: materi pokok IPS bertujuan untuk menidentifikasi masalah/persoalan keseimbangan lingkungan, karakteristik dataran tinggi, rendah, dan pantai serta pemanfaatan sumber daya alamnya demi kesejahteraan masyarakat melalui kegiatan pembelajaran berkaitan dengan cara menghargai dan menyelamatkan lingkungan; keberagaman tumbuhan yang bisa dimanfaatkan sebagai makanan pokok seperti sagu, singkong, padi (beras) dan lain sebagainya; bentuk muka bumi yang meliputi: pantai, dataran rendah, dan dataran tinggi; serta karakteristik alam.

b. Pembelajaran 5: terdiri dari karakteristik ruang dan pemanfaatan sumber daya alam di lingkungan sekitar; jenis-jenis tanaman dan tempat tumbuhnya; 2) kondisi dan karakteristik alam sekitar yakni: iklim, lapisan tanah, dan bentuk muka bumi; 3) melakukan refleksi mengenai pertumbuhan dan perawatan hewan.

Pada subtema ini, dapat dipahami bahwa tumbuhan memberikan banyak manfaat bagi manusia sebagai makanan sehari-hari. Selain sebagai makanan pokok, tumbuhan juga bisa dipergunakan untuk karya seni. Namun, setiap tumbuhan tersebut mempunyai kondisi dan karakteristik alam yang bebeda, dan sangat berpengaruh terhadap jenis tumbuhan yang hidup disekitar wilayah tersebut. Untuk itu, mencari tahu bagaimana cara belajar dari lingkungan berkaitan dengan menghargai, menyelamatkan dan menjaga keseimbangan lingkungan serta mengetahui kondisi dan karakteristik alam disekitar (iklim, lapisan tanah, dan bentuk muka bumi) penting dilakukan, sehingga karakteristik tersebut dapat dimanfaatkan untuk mengetahui tumbuhan apa saja yang cocok tumbuh diwilayah tertentu. Dengan demikian, sikap yang terkandung atau nilai yang dikembangkan dalam subtema ini ialah disiplin, tanggung jawab, dan peduli. 


\section{Subtema 2: Keberagaman Makhluk Hidup di Lingkunganku}

Tujuan dan kegiatan pembelajaran materi pokok IPS dalam subtema 2 dapat di uraikan sebagai berikut:

a. Pembelajaran 1: terdiri dari mengidentifikasi pemanfaatan sumber daya alam hayati untuk kesejahteraan masyarakat; manfaat dari peduli dan melestarikan sumber daya alam dan lingkungan yang terdiri dari menjaga keseimbangan alam dan kelestarian hewan, serta dampaknya terhadap kepunahan hewan dan menyebabkan kerusakan lingkungan dan upaya untuk melestarikan hewan seperti tidak berburu dan menebang pohon.

b. Pembelajaran 5: terdiri dari karakteristik ruang dan pemanfaatan sumber daya alam dilingkungan sekitar, karakteristik tempat hidup hewan yang meliputi: ayam, itik, kucing dan ikan, keadaan alam yang terdiri dari iklim dan bentuk muka bumi mempunyai pengaruh yang besar terhadap kehidupan alam.

Secara garis besar, subtema ini membahas tentang sumber daya alam dan keseimbangan lingkungan, kondisi alam dan pemanfaatan sumber daya alamnya serta karakteristik lingkungan dan sumber daya alam. Indonesia mempunyai ribuan jenis hewan di darat dan di laut, yang mana hewan-hewan tersebut merupakan sumber daya alam hayati yang dimanfaatkan sebagai alat pemenuhan kebutuhan manusia. Disamping itu juga menjadi ciri identitas bangsa Indonesia. Oleh karena itu, sebagai sumber daya alam, tentu harus dijaga keberadaannya. Apabila hewan-hewan tersebut tidak dijaga, maka ia menjadi langka dan terancam punah. Sama halnya yang terjadi pada burung cenderawasih. Selain burung yang mempunyai warna bulu yang indah indah, perburuan sering terjadi pada kupu-kupu disebabkan warnanya yang sangat indah, sehingga menarik perhatian banyak orang. kupukupu di Indonesia mempunyai jenis yang banyak dibandingkan negara lain, diantaranya kupu-kupu sayap burung peri, kupu-kupu raja, dan kupu-kupu trogon.

Dengan demikian, melalui tujuan dan kegiatan pembelajaran yang dipaparkan di atas, dapat diketahui bahwa karakter yang dikembangkan pada subtema 2 ini terdiri dari peduli dan tanggung jawab.

\section{Subtema 3: Ayo Cintai Lingkungan}

Pada subtema ini, tujuan dan kegiatan pembelajaran materi pokok IPS dapat disajikan sebagai berikut: 
a. Pembelajaran 1: terdiri dari merefleksi kebiasaan peduli dan melestarikan sumber daya alam dan lingkungan, manfaat tumbuhan dan hewan apabila dirawat dengan baik, ciriciri tumbuhan dan hewan yang terawat dan tidak terawat, merawat hewan dan tumbuhan sebagai bentuk perilaku cinta lingkungan misalnya melakukan penghijauan, dan dampak apabila tidak menjaga lingkungan.

b. Pembelajaran 5: dapat menerangkan informasi pemanfaatan dan pelestarian sumber daya alam dilingkungan, menjaga keseimbangan dan kelestarian lingkungan, memanfaatkan sumber daya alam secara bijak, sikap yang mencerminkan tidak mencintai lingkungan.

Salah satu sikap peduli lingkungan ialah dengan menjaga dan melestarikan lingkungan alam. sikap ini merupakan bentuk dari rasa syukur atas nikmat Tuhan yang maha Esa sekaligus wujud dari sikap kita sebagai manusia yang beradab dan teladan bagi lingkungan. menjaga kelestarian lingkungan bisa dilakukan dengan cara sederhana seperti membuang sampah pada tempatnya, menghemat penggunaan kertas, merawat tumbuhan dan hewan dirumah, menjaga hewan dan tumbuhan dimana pun kita berada (tidak memetik bunga, buah, dan lain sebagainya). Melalui kegiatan tersebut, siswa difasilitasi dengan observasi, mengamati gambar, berdiskusi, dan membaca teks berkaitan dengan kegiatan ayo cintai lingkungan. Dengan demikian, nilai-nilai karakter yang dikembangkan pada tema 3 yaitu disiplin, peduli lingkungan, tanggung jawab dan religius.

Berkaitan dengan data yang diiperoleh di atas, maka dapat tarik kesimpulan bahwa keseimbangan lingkungan terdiri dari sumber daya alam, yang didefinisikan sebagai segala sesuatu yang berasal dari alam dan mempunyai manfaat untuk manusia. berdasarkan jenisnya, sumber daya ada yang berasal dari makhluk hidup (hewan dan tumbuhan) serta keadaan alam (iklim, lapisan tanah, dan bentuk muka bumi). Selanjutnya, pada tema tersebut juga menanamkan kebiasaan-kebiaasaan baik dalam melestarikan lingkungan seperti: menggalakkan penanaman pohon, terutama jenis pohon yang menyerap air; menjaga kelestarian hutan sebagai cadangan air, bijak dalam menggunakan air, tidak membuang limbah berbahaya kedalam aliran sungai, memupuk tanah, mendaur ulang sampah plastik, mengelola lahan yang tandus, menjaga keberadaan satwa yang berada didalamnya, hal ini disebabkan pohon-pohon dan satwa saling bergantungan satu sama lain. Kebiasaan tersebut dapat membentuk karakter peduli lingkungan terhadap diri siswa yang di bentuk sejak usia sekolah dasar, mengingat banyaknya tangan yang tidak bertanggung jawab seperti menebang pohon, membuang sampah sembarangan, memburu satwa dan lain sebagainya. Untuk itu, merawat, menjaga dan melestarikan keseimbangan lingkungan penting dilakukan. 
Berdasarkan hasil analisis tersebut, dapat disimpulkan bahwa lingkungan hidup merupakan bagian dari integritas manusia. Oleh karena itu, ia di pandang sebagai salah satu ekosistem yang mempunyai value untuk dihormati, dihargai dan dijaga. Integritas yang dimaksud disini ialah segala perbuatan manusia yang dapat menyebabkan baik/buruk pengaruhnya terhadap lingkungan, termasuk didalamnya menyebabkan manusia mempunyai tanggung jawab. Manusia dan lingkungan mempunyai hubungan yang sangat erat sebab Allah swt. menciptakan alam ini beserta isinya termasuk didalamnya manusia dan lingkungan dalam keseimbangan dan keserasian, yang mana dua hal ini harus dijaga supaya tidak mengalami kerusakan, karena apabila salah satu unsur rusak, maka akan berpengaruh terhadap unsur lainnya.

Adapun nilai-nilai keislaman yang terdapat pada tema peduli terhadap makhluk hidup berdasarkan hasil analisis terdapat 3 nilai keislaman, yakni: 1) Nilai Aqidah: religius (QS. QS.Luqman: 13-19) dan tanggung jawab (QS. Al-Mudatstsir:38; Ash-Shaffat:22-24; Yaasiin:12; dst.); 2) Nilai Ibadah: peduli lingkungan (QS. Ar-Rum: 41-42; Al-A'raf: 56-58), hal ini berkaitan dengan tata cara menjaga dan melestarikan keseimbangan alam/lingkungan sebagai bentuk sikap rasa syukur kepada Allah dengan cara membuang sampah pada tempatnya, menghemat penggunaan kertas, tidak melakukan perburuan terhadap hewan, dan merawat tumbuhan dengan cara tidak memetik bunga, bakal, buah dan mengumpulkan dedaunan kering yang digunakan untuk pembuatan pupuk kompos; dan 3) Nilai Akhlak meliputi tanggung jawab dijelaskan dalam QS. Al-Mudatstsir: 38; Ash-Shaffat: 22-24; dan Yaasiin:12; dst., dan disiplin dalam QS. Al-Ashr: 1-3 dan An-Nisa:59. Hal ini berkaitan senada dengan nilai-nilai karakter Islam yang dijelaskan (Isbandiyah \& Ningsih, 2020:10) dalam penelitiannya yang menyatakan bahwa: 1) nilai aqidah terdiri dari nilai religius, tanggung jawab, toleransi, dan jujur; 2) nilai ibadah meliputi: menghargai prestasi, peduli sosial, peduli lingkungan, gemar membaca, rasa ingin tahu, mandiri, dan tekun; sedangkan 3) nilai akhlak mencakup disiplin, komunikatif, dan demokratis. Dengan demikian, dapat dikatakan bahwa lingkungan hidup merupakan bagian dari integritas manusia. Dan di pandang sebagai salah satu ekosistem yang mempunyai value untuk dihormati, dihargai dan dijaga yang meliputi segala perbuatan manusia yang dapat menyebabkan baik/buruk pengaruhnya terhadap lingkungan, termasuk didalamnya menyebabkan manusia mempunyai tanggung jawab. 


\section{PENUTUP}

Nilai-nilai keislaman yang terdapat pada materi pokok Ilmu Pengetahuan Sosial (IPS) dalam buku teks terbitan kementerian pendidikan dan kebudayaan edisi revisi 2017 tema 3 "Peduli Terhadap Makhluk Hidup" untuk siswa SD/MI kelas IV secara keseluruhan sudah memenuhi kriteria nilai-nilai keislaman yang terdiri dari, nilai aqidah berupa religius dan tanggung jawab, nilai ibadah berupa tata cara peduli lingkungan dan nilai akhlak berupa disiplin. Namun, dari masing-masing nilai-nilai keislaman hanya satu sikap diantara 18 sikap yang dikembangkan Kementerian Pendidikan Nasional, kecuali nilai aqidah. Mengenai hal ini, seorang pendidik diharapkan dapat mengembangkan potensi dan kreativitasnya dalam memasukkan/mengajarkan nilai-nilai keislaman pada materi pembelajaran cakupan yang lebih luas lagi sebagaimana 18 sikap yang di kembangkan Kementerian Pendidikan Nasional.

\section{DAFTAR PUSTAKA}

'Abdul bin 'Abdul Hamid al-Atsari. (2006). Intisari 'Aqidah Ahlus Sunnah wal Jama'ah. Pustaka Imam Asy-Syafi'i.

Anggari, A. St., Afriki, Wulan, D. R., Puspitawati, N., Khasanah, L. M., \& Hendriyeti, S. (2017). Buku Guru: Peduli Terhadap Makhluk Hidup Tema 3 Buku Tematik Terpadu Kurikulum 2013-Edisi Revisi 2017. Kementerian Pendidikan dan Kebudayaan.

Arikunto, S. (2020). Prosedur Penelitian Suatu Pendekatan Praktis. Rineka Cipta.

Arisona, R. D. (2017). Integrasi Nilai-Nilai Islam dalam Pembelajaran IPS di MI. Proceeding Ancoms, 330.

Darmawan, D. (2013). Metode Penelitian Kualitatif. Remaja Rosdakarya.

Depdiknas. (n.d.). Undang-Undang Republik Indonesia Nomor 20 Tahun 2003 tentang Sistem Pendidikan Nasional. Dirjen Pendidikan Dasar dan Menengah.

Efendi. (2016). Pendidikan Islam Transformatif Ala KH. Abdurrahman Wahid. Guepedia.

Fitriani, F. (2016). Pengembangan Bahan Ajar Kimia Terintegrasi Nilai-Nilai Spiritual untuk Kelas XI SMA/MA Semester I Berdasarkan Kurikulum 2013. Tesis: Pascasarjana UNIMED, 19.

Hakim, \& Imam Nur. (2014). Pembelajaran Tematik-Integratif di SD/MI dalam Kurikulum 2013. Insania, Vol.19 No., 46.

Hasan, S. H., \& Dkk. (2010). Pengembangan Pendidikan Budaya dan Karakter Bangsa: Bahan Pelatihan Penguatan Pembelajaran Berdasarkan Nilai-Nilai untuk Membentuk Daya Saing dan Karakter Bangsa. Pusat Kurikulum Departemen Pendidikan Nasional, $7-11$.

Isbandiyah, \& Ningsih, W. (2020). Analisis Nilai-Nilai Karakter Islam dalam Pembelajaran IPS Di MTS Mazro'illah Lubuklinggau. Jurnal PIPSI (Pendidikan Ilmu Pengetahuan Sosial Indonesia), Vol. $\quad 5 \quad$ No. 
https://journal.stkipsingkawang.ac.id/index.php/JurnalPIPSI/article/view/1468

Kholidah, L. N. (2015). Pola Integrasi Nilai-Nilai Keislaman dalam Pembelajaran Pendidikan Agama Islam pada Lembaga Pendidikan. Jurnal At-Ta'dib, Vol.10 No., 325-340.

Miles, M. B., \& Huberman, M. (1992). Analisis Data Kualitatif. UI Press.

Muftisany, H. (2016). Mengenal Ibadah Mahdhah dan Ghairu Mahdhah. Republika.Co.Id.

Muliawan, J. U. (2014). Metodologi Penelitian Pendidikan dengan Studi Kasus. Gava Media.

Mulyana, R. (2004). Mengartikulasikan Pendidikan. Alfabeta.

Mumpuni, A. (2018). Integrasi Nilai Karakter dalam Buku Pelajaran: Analisis Konten Buku Teks Kurikulum 2013. Deepublish: Budi Utama.

Peraturan Menteri Pendidikan dan Kebudayaan Republik Indonesia, Salinan Lampiran Nomor 8 tentang Buku yang digunakan oleh Satuan Pendidikan (p. 1). (2016).

Peraturan Menteri Pendidikan dan Kebudayaan Republik Indonesia, Tentang Buku Teks Pelajaran dan Buku Panduan Guru untuk Pendidikan Dasar dan Meenengah Nomor 71 (p. 1). (2013).

Ramdhani, D. (2015). Penanaman Nilai-Nilai Keislaman Dalam Pendidikan Agama Islam Di KMI Pondok Pesantren Darusy Syahadah Simo Boyolali Tahun Pelajaran 2015/2016. Universitas Muhammadiyah Surakarta.

Rasyid, D. (2000). Islam dalam Berbagai Dimensi (Cetakan II). Gema Insani Press.

Riyadi, I. (2015). Model Pembelajaran Berbasis Metakognisi Untuk Peningkatan Kompetensi Siswa pada Mata Pelajaran IPS. Deepublish: Budi Utama.

Safrida, \& Andayani, D. (2016). Aqidah dan Etika Dalam Biologi. Syiah Kuala University Press.

Susanto, A. (2014). Pengembangan Pembelajaran IPS di Sekolah Dasar. Prenadamedia Group.

Suwito. (2004). Filsafat Pendidikan Akhlak Ibnu Miskawaih. Remaja Rosdakarya.

Suyatinah. (2001). Analisis Buku Teks Bahasa Indonesia Sekolah Dasar Kelas II. Laporan Penelitian FIP-UNY.

Tim Pengembangan Ilmu Pendidikan FIP-UPI. (2007). Ilmu dan Aplikasi Pendidikan; Bagian 3: Pendidikan Disiplin Ilmu (Cet.II). Imperial Bhakti Utama (IMTIMA).

Trianto. (2010). Pengantar Penelitian Pendidikan Bagi Pengembangan Profesi Pendidikan dan Tenaga Kependidikan. Kencana.

Triyanto. (2011). Desain Pengembangan Pembelajaran Tematik bagi Anak Usia Dini TK/RA dan Anak Usia Kelas Awal SD/MI. Kencana Prenada Media Group.

Yusuf, Y. M. (2017). Metode Penelitian: Kuantitatif, Kualitatif, dan Penelitian Gabungan. Kencana.

Zed, M. (2004). Metode Penelitian kepustakaan. Yayasan Obor Indonesia.

Rina Rahmi | Nilai-Nilai Keislaman pada Materi Pokok IPS dalam Buku Tematik kelas IV SD/MI Tema

"Peduli Terhadap Makhluk Hidup" | 101 